\title{
Relative radio-opacity of commonly consumed fish species in South East Queensland on lateral neck x-ray: an ovine model
}

\author{
William R A Davies and Patricia J Bate
}

S ymptoms of a possible foreign body in the upper aerodigestive tract are a common presentation in emergency medicine. The fishbone is the most common, comprising $60 \%$ of presentations in one study. ${ }^{1}$ Patients can experience a sharp pain in the throat after a meal containing fish. Bones may lodge in the fauces. Once they pass the isthmus of the fauces, the common sites of impaction are the piriform sinus and vallecula, but bones may also lodge distally in the oesophagus. During this progression the bone may perforate the viscera, with potentially serious complications, such as retropharyngeal abscess, mediastinitis, hepatic abscess or oesophago-aortic fistula. ${ }^{1,2}$

When a patient presents with sharp throat pain after eating fish, the chance of identifying a foreign body is relatively low. One study suggested that a bone is found in only $21 \%$ of such cases. ${ }^{3}$

Lateral soft tissue neck x-ray may have limited clinical utility, yet it is the most common first-line investigation in cases of suspected fishbone impaction. ${ }^{4-6}$

The sensitivity and specificity of plain x-rays for detecting fishbones in the soft tissues of the neck have been considered by several investigators. Their results are summarised in Box 1. ${ }^{4-8}$

There is controversy about the usefulness of lateral soft tissue neck $\mathrm{x}$-rays for assess-

\section{ABSTRACT}

Objective: To determine the relative radio-opacity on plain x-ray of bones of fish species commonly consumed in South East Queensland.

Design: A cadaveric sheep model was used to mimic the soft tissues of a human neck. Bones of 10 fish species were placed in the paratracheal tissues and adjacent to the larynx. X-rays were taken and the images (including four control images with no bones) were incorporated into a Microsoft PowerPoint presentation to be interpreted by emergency specialists and registrars. Observers were blinded to which specimens contained fishbones and which did not.

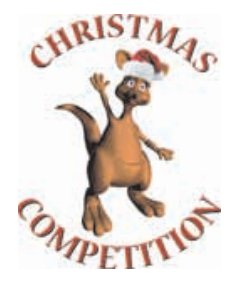

Main outcome measures: Sensitivity and specificity of plain x-rays for detecting impacted fishbones.

Results: Significant interobserver variability was identified. Despite this, the overall specificity of plain $x$-rays was $90 \%$. The sensitivity of the technique was $79 \%$ overall, but varied significantly between fish species.

Conclusion: Lateral soft tissue neck $x$-ray is an appropriate screening tool in cases of a suspected impacted fishbone. If a fishbone is identified on $x$-ray, the patient should be referred for endoscopy without further imaging. X-ray may be of limited value in cases of Dory or Spanish mackerel bone ingestion. In such cases, a computed tomography scan should be the first-line investigation.

MJA 2009; 191: 677-680

ing cases of suspected fishbone impaction. A search of the "Best BETs" website produces two reviews of the literature. One concludes that "lateral neck x-rays are not indicated in the emergency department management of suspected fish bone impaction". 9 The second states that, compared with computed tomography, "plain radio- graphy is also specific enough for positive results to warrant oesophagoscopy without any further imaging, and should thus continue being utilised as the first line radiological investigation". 10

Other authors have concluded that the efficacy of plain $\mathrm{x}$-rays will depend on the relative radio-opacity of the bones, and

1 Sensitivity and specificity of plain x-rays for detecting impacted fishbones in the oropharynx: a review of past studies

\begin{tabular}{|c|c|c|c|c|c|}
\hline $\begin{array}{l}\text { First author } \\
\text { (country, date) }\end{array}$ & Patient demographics & $\begin{array}{l}\text { Study } \\
\text { design }\end{array}$ & Results & $\begin{array}{l}\text { Study } \\
\text { weaknesses }\end{array}$ & Fish species used \\
\hline $\begin{array}{l}\text { Ngan } \\
\text { (Hong Kong, }_{1990)^{5}}\end{array}$ & $\begin{array}{l}310 \text { patients complaining of symptoms of } \\
\text { fishbone impaction. Initial plain x-rays were } \\
\text { compared with endoscopic findings }\end{array}$ & $\begin{array}{l}\text { Prospective } \\
\text { diagnostic }\end{array}$ & $\begin{array}{l}\text { Sensitivity } 32 \% \\
\text { specificity } 91 \%\end{array}$ & $\begin{array}{l}\text { No analysis of } \\
\text { species differences }\end{array}$ & $\begin{array}{l}\text { Grass carp, goldfish, } \\
\text { grouper and golden thread }\end{array}$ \\
\hline $\begin{array}{l}\text { Evans } \\
\text { (Hong Kong, } \\
1992)^{4}\end{array}$ & $\begin{array}{l}100 \text { lateral soft tissue neck } x \text {-rays with } \\
\text { known fishbones were mixed with } 100 \\
\text { control x-rays }\end{array}$ & $\begin{array}{l}\text { Blinded } \\
\text { retrospective } \\
\text { diagnostic }\end{array}$ & $\begin{array}{l}\text { Sensitivity } 25.3 \% \\
\text { specificity } 86.3 \%\end{array}$ & $\begin{array}{l}\text { No analysis of } \\
\text { species differences }\end{array}$ & $\begin{array}{l}\text { Grass carp, grouper and } \\
\text { golden thread }\end{array}$ \\
\hline $\begin{array}{l}\text { Sundgren } \\
\text { (Sweden, } \\
1994)^{6}\end{array}$ & No demographics available & $\begin{array}{l}\text { Retrospective } \\
\text { diagnostic }\end{array}$ & $\begin{array}{l}\text { Sensitivity } 28.6 \% \\
\text { specificity } 87.5 \%\end{array}$ & $\begin{array}{l}\text { Small numbers, } \\
\text { no analysis of } \\
\text { species differences }\end{array}$ & $\begin{array}{l}\text { Salmon, cod, ling and } \\
\text { herring }\end{array}$ \\
\hline $\begin{array}{l}\text { Lue } \\
\text { (USA, } \\
2000)^{8}\end{array}$ & & $\begin{array}{l}\text { Blinded } \\
\text { cadaveric }\end{array}$ & $\begin{array}{l}\text { Sensitivity } 39 \% \\
\text { specificity } 72 \%\end{array}$ & & $\begin{array}{l}\text { Large-mouth bass, catfish, } \\
\text { drum, flounder, red snapper, } \\
\text { redfish, salmon and trout }\end{array}$ \\
\hline $\begin{array}{l}\text { Akazawa } \\
(\text { Japan, } \\
2004)^{7}\end{array}$ & $\begin{array}{l}\text { Plain x-rays were compared with computed } \\
\text { tomography scans in } 76 \text { patients complaining } \\
\text { of symptoms of fishbone impaction }\end{array}$ & $\begin{array}{l}\text { Prospective } \\
\text { diagnostic }\end{array}$ & $\begin{array}{l}\text { Sensitivity } 64.5 \% \\
\text { specificity } 100 \%\end{array}$ & $\begin{array}{l}\text { Authors } \\
\text { miscalculated } \\
\text { sensitivity as } 54.8 \%\end{array}$ & Unknown \\
\hline
\end{tabular}




\section{CHRISTMAS OFFERINGS}

this may account for some of the variability in sensitivity and specificity in previous trials. ${ }^{8,11}$

\section{METHODS}

\section{Fishbone selection}

A number of fishbones were removed from specimens of 10 species of fish commonly eaten in South East Queensland. The species were selected after discussion with managers of fish counters of four branches of two major supermarkets and two independent fishmongers supplying both the general public and restaurants in the area. Uncooked specimens were used, as previous studies have shown no difference in radioopacity between cooked and uncooked specimens. 8,12 The bones were between $2 \mathrm{~cm}$ and $2.5 \mathrm{~cm}$ in length, where possible. This was the mean length of bones found in a study by Sundgren et al. ${ }^{6}$

\section{Specimen selection and bone placement}

A sheep neck was used as a soft tissue model, as it closely conformed to the body habitus of patients seen in the emergency department. The circumference of the specimen neck was $36 \mathrm{~cm}$, which was comparable to that of male human necks as documented by Vasavada et al. ${ }^{13}$ Other cadaveric studies have used a swine model, but swine specimens available to us were too large to mimic a normal human neck. Our specimen was sourced from Highchester Abattoir, Beaudesert, Queensland, supplier of cadaveric specimens to Griffith University School of Medicine, with a letter of authority from the university.

The specimen was prepared by removing excess wool and dissecting the laryngopharynx. The fishbones were placed in the paratracheal tissues and adjacent to the larynx (Box 2, A).

\section{Radiographic images}

$\mathrm{X}$-rays were taken with an exposure of $109 \mathrm{kV}$ and $3.6 \mathrm{~mA} / \mathrm{s}$ using a Kodak digital radiography system. This was one of the standard soft tissue human neck radiographic protocols used in the radiology department in which the imaging was conducted. The images produced were comparable to human images on file. This confirmed that a sheep neck was an appropriate model for the human neck.

A total of 14 films (10 containing bones and four without bones, as controls) were

\section{Placement of fishbones in the specimen}

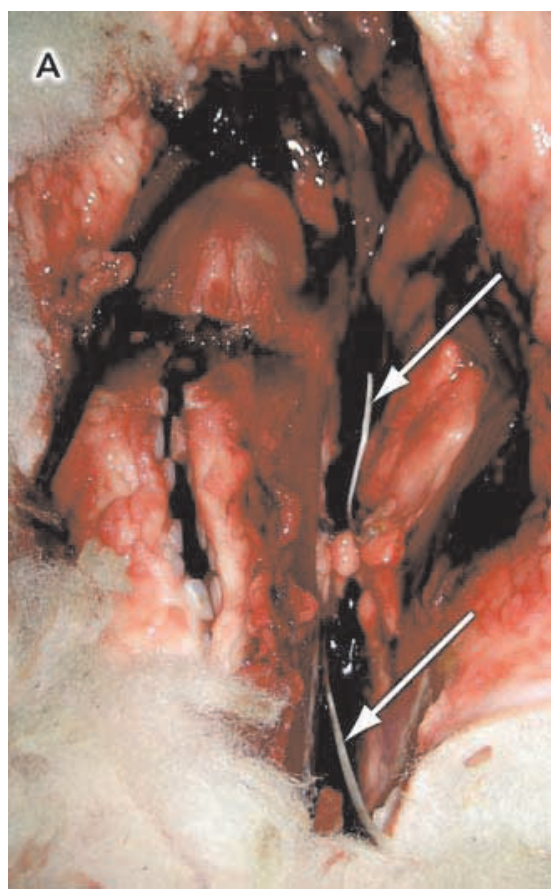

A: Dissection of the laryngotracheal region, showing two fish bones (arrows) placed in tissues adjacent to the aerodigestive tract.

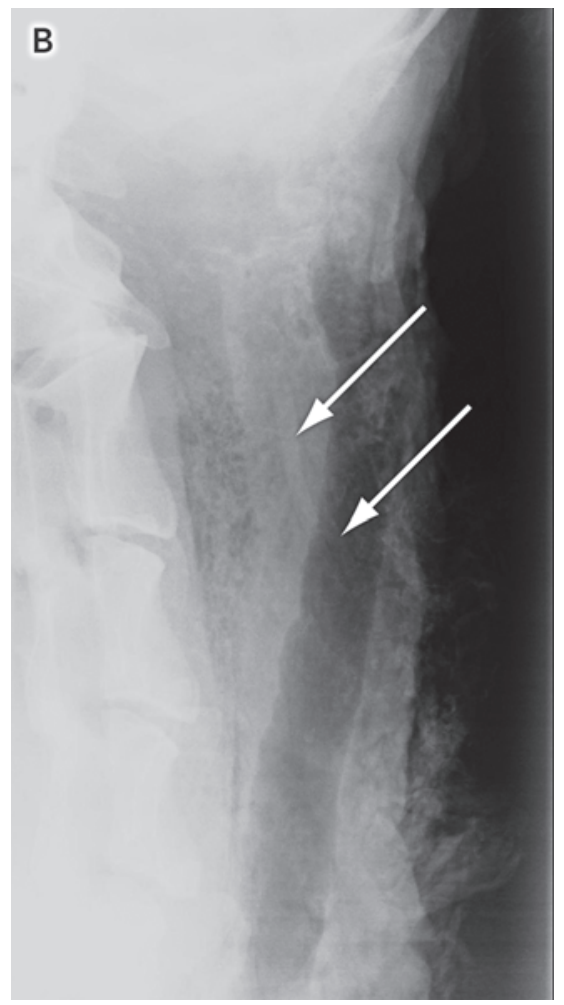

B: Radiographic image showing fish bones (arrows) in the soft tissue of the aerodigestive tract. taken and stored on removable hardware. A DICOM Editor was used to convert the images into digital images in JPEG (Joint Photographic Experts Group) format, with the standard compression defined in the Java Image I/O Tools library (a system that produces minimal loss in image quality) (Box 2, B).

A Microsoft PowerPoint 2003 presentation was prepared to demonstrate the 10 images containing bones and the four control images. There was no indication on the images as to which specimens contained bones.

\section{Questionnaire}

A questionnaire was prepared asking each observer to rate the visibility of any fishbone seen on a numerical scale from 0 to $3(0=$ no bone seen; 1 = a poorly visualised bone; 2 = an adequately visualised bone; 3 = a well visualised bone). Observers were also asked how many bones were seen on the image.

The PowerPoint presentation and questionnaire were distributed via email to registrars in emergency medicine and Fellows of the Australasian College for Emergency Medicine. To preserve image size, observers were asked to view the images on a 17 -inch screen or larger.

\section{Statistical analysis}

The Wilcoxon signed rank test was used to test for any difference in median visibility scores between x-rays with fishbones and $\mathrm{x}$-rays without. A Friedman test was used to test for any significant difference in bone visibility between fish types. We used Stata software, version 1 (StataCorp, College Station, Tex, USA).

\section{RESULTS}

Out of 48 questionnaires, 15 were returned. All responses were anonymous, and all questionnaires were completed appropriately, with no omitted responses.

Results of the Wilcoxon signed rank test showed that the difference in fishbone visibility scores between $x$-rays containing bones and control $x$-rays was significant $(z=-2.05$; $P<0.04$ ), with scores being lower for control $\mathrm{X}$-rays than those containing bones.

The medians and ranges of the visibility scores for bones from each type of fish are shown in Box 3. The figure suggests that there were differences in bone visibility between the fish species - in particular, that Dory bones were less visible than other fishbones, but this difference was not sup- 
ported by the statistical analysis. A Friedman test performed on the visibility scores failed to identify a significant difference in bone visibility between fish types (Friedman $\chi^{2}$ score $\left.=19.47 ; P>0.1\right)$.

\section{Medians and ranges of visibility scores for fishbones, by type of fish}

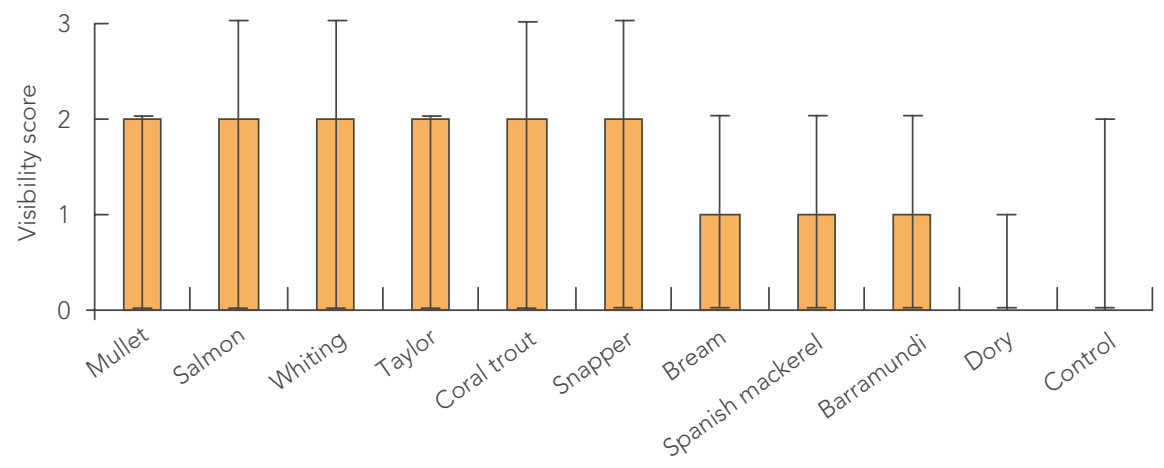

Boxes represent the medians and lines represent the ranges.

\section{Proportion of observers who identified a bone was present (sensitivity) for} each type of fish, and population estimates for these proportions

\begin{tabular}{lcc} 
Fish & $\begin{array}{c}\text { Proportion of observers who } \\
\text { identified a bone was present }\end{array}$ & $\begin{array}{c}\text { Sensitivity: population estimate } \\
\text { of proportion (95\% Cl) }\end{array}$ \\
\hline Bream & $14 / 15$ & $0.93(0.61-0.99)$ \\
Mullet & $14 / 15$ & $0.93(0.61-0.99)$ \\
Whiting & $14 / 15$ & $0.93(0.61-0.99)$ \\
Coral trout & $15 / 15$ & $1.00(0.69-1.00)$ \\
Taylor & $12 / 15$ & $0.80(0.47-0.95)$ \\
Salmon & $14 / 15$ & $0.93(0.61-0.99)$ \\
Spanish mackerel & $8 / 15$ & $0.53(0.25-0.80)$ \\
Barramundi & 1315 & $0.87(0.62-0.96)$ \\
Snapper & $15 / 15$ & $1.00(0.80-1.00)$ \\
Dory & $7 / 15$ & $0.47(0.20-0.75)$ \\
Overall sensitivity $^{*}$ & $120 / 150$ & $0.79(0.72-0.85)$ \\
Overall specificity $^{\dagger}$ & $54 / 60$ & $0.90(0.80-0.95)$ \\
\hline
\end{tabular}

* Proportion of true positives. † Proportion of true negatives.

5 Mean fishbone visibility score plotted against sensitivity for the 10 fish types

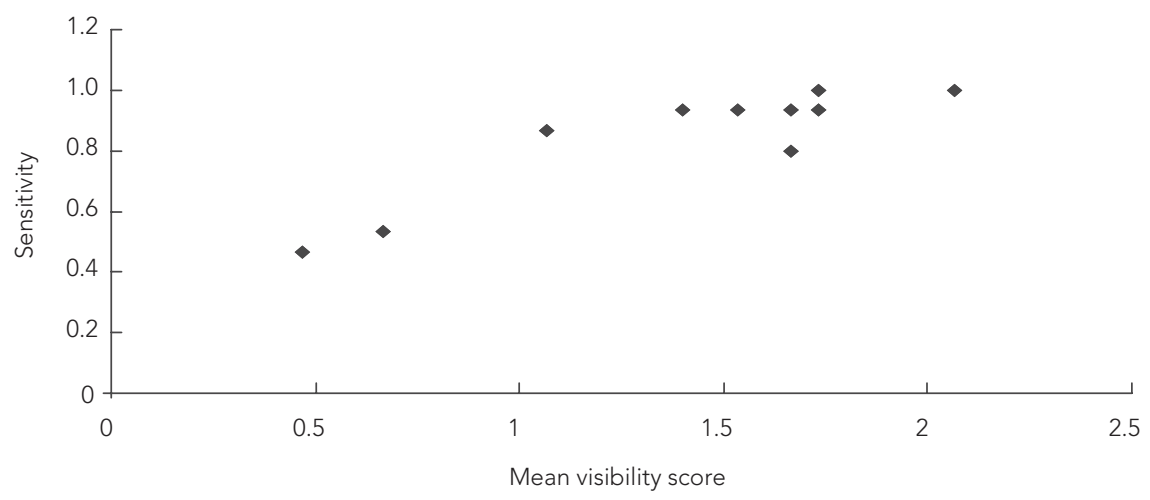

species in the sensitivity of bone detection by different observers. ${ }^{14}$ This was consistent with results of statistical analysis: a $\chi^{2}$ test conducted on the sensitivity values failed to identify a difference between fishbone types $\left(\chi^{2}=5.75\right.$; critical value, $\left.16.92 ; d f=9\right)$.

To examine the relationship between perceived ease of bone visualisation and the calculated sensitivity for each type of fish, the visibility score was plotted against sensitivity (Box 5). The upward trend in the data suggests that observers were more likely to identify the presence of a bone in x-rays containing bones whose visibility they rated highly than in x-rays containing bones with lower visibility scores. This effect supports the internal validity of our study.

\section{DISCUSSION}

The use of an ovine model for radiological assessment of the relative opacity of a foreign body is appropriate. The neck of the specimen was comparable in circumference to that of the human neck, and the exposures needed were the same as for an equivalently proportioned human.

As it was conceivable that the presence of a significant amount of wool would impair the images, the wool was removed before $\mathrm{x}$-ray. However, the removal of wool was time-consuming and possibly unnecessary. Before conducting any further studies of this type, it may be useful to assess whether or not wool impairs the image quality.

The positioning of the bones adjacent to the larynx or in the paratracheal tissue was thought to be a reasonable approximation to the clinical situation. The $\mathrm{x}$-ray radiation would have to pass through the same series of tissue planes before producing an image. Placing the bones in the aerodigestive tract itself would create technical difficulties in the positioning and could lead to significant variabilty of final location of the bones. We did not attempt to identify the anatomical positions in which the bones would be most or least easily visualised. A standard location was preferred.

The conversion of $x$-ray images into JPEG files to be used in the PowerPoint presentation distributed to respondents may have led to image degradation and a variation in the size of images assessed by the observers. This may have contributed to interobserver variability. Ideally, the images should be viewed on DICOM viewers such as those that are available to radiology departments and emergency departments with fully digital radiology. 


\section{CHRISTMAS OFFERINGS}

The 90\% specificity for the modality found in our trial is within the range of $72 \%-100 \%$ quoted by previous investigators. $^{4-8}$ The overall sensitivity of $79 \%$ was higher than sensitivities noted previously. ${ }^{4-8}$ This may reflect the use of digital $\mathrm{x}$-rays in our study compared with the non-digital $\mathrm{x}$-rays used in some previous studies.

It has been suggested that differences in the radio-opacity of fishbones are related to the fishes' habitat - the bones of saltwater fish being radio-opaque and those of freshwater fish being radiolucent. ${ }^{15}$ The species used in our study all spend most of their lifecycles in saltwater. This may also contribute to the increased sensitivity of the imaging.

In the clinical situation, it is not always clear what species has been consumed. In particular, fish purchased from fast food establishments are often not clearly identified. However, if a more expensive species is eaten, or the food is prepared at home, the patient will often be able to identify the fish. ${ }^{11}$

\section{CONCLUSION}

The value of lateral soft tissue neck $\mathrm{x}$-ray for assessment of a patient with a suspected fish bone impaction is a controversial issue. Our findings suggest it would be reasonable to undertake $\mathrm{x}$-ray as the first-line radiological examination for patients in whom direct examination of the oral cavity is negative. If a fishbone is identified, the patient should undergo endoscopy without further imaging.

\section{ACKNOWLEDGEMENTS}

We thank all our anonymous colleagues who gave their valuable time to study and complete the questionnaire. Many thanks to Teleah North, whose expertise in radiography was essential to the execution of our study.

\section{COMPETING INTERESTS}

None identified.

\section{AUTHOR DETAILS}

William R A Davies, MB BS, Retrieval Medical Officer $^{1}$

Patricia J Bate, PhD, MAppSci, BAppSc(Phty), Senior Lecturer in Preclinical Sciences, Research and Evaluation ${ }^{2}$

1 Alice Springs Hospital, Alice Springs, NT.

2 Northern Territory Clinical School, Royal

Darwin Hospital Campus, Darwin, NT.

Correspondence: willdavies72@hotmail.com

\section{REFERENCES}

1 Nandi P, Ong GB. Foreign body in the oesophagus: review of 2394 cases. Br J Surg 1978; 65: 5-9.

2 Masunaga S, Abe M, Imura $T$, et al. Hepatic abscess secondary to a fishbone penetrating the gastric wall: CT demonstration. Comput Med Imaging Graph 1991; 15: 113-116.

3 Knight LC, Lesser TH. Fish bones in the throat. Arch Emerg Med 1989; 6: 1-6.

4 Evans RM, Ahuja S, Rhys Williams S, et al. The lateral neck radiograph in suspected impacted fish bones - does it have a clinical role? Clin Radiol 1992; 46: 121-123.

$5 \mathrm{Ngan}$ JH, Fok PJ, Lai EC, et al. A prospective study on fish bone ingestion. Experience of 358 patients. Ann Surg 1990; 211: 459-462.
6 Sungren PC, Burnett A, Maly PV. Value of radiography in the management of possible fishbone ingestion. Ann Otol Rhinol Laryngol 1994; 103: 628-631.

7 Akazawa Y, Watanabe S, Nobukiyo S, et al. The management of possible fish bone ingestion. Auris Nasus Larynx 2004; 31: 413-416.

8 Lue AJ, Fang WD, Manolidis S. Use of plain radiology and computed tomography to identify fish bone foreign bodies. Otolaryngol Head Neck Surg 2000; 123: 435-438.

9 Bethune L. Lateral neck x-rays are not indicated in the emergency department management of suspected fish bone impaction. Best BETs best evidence topics. 2000. http://www.bestbets.org/bets/bet.php?id=29 (accessed May 2009).

10 Debasis D. Is CT effective in cases of oesophageal fish bone ingestion? Best BETs best evidence topics. 2007. http://www.bestbets.org/ bets/bet.php?id=1125 (accessed May 2009)

11 Ell SR, Sprigg A, Parker AJ. A multi-observer study examining the radiographic visibility of fishbone foreign bodies. J R Soc Med 1996; 89: 31-34.

12 Carr AJ. Radiology of fish bone foreign bodies in the neck. J Laryngol Otol 1987; 101: 407-408.

13 Vasavada A, Danaraj J, Siegmund G. Head and neck anthropometry, vertebral geometry and neck strength in height-matched men and women. J Biomech 2008; 41: 114-121.

14 Newcombe RG. Two-sided confidence intervals for the single proportion: comparison of seven methods. Stat Med 1998; 17: 857-872.

15 Dunn R. ENT and faciomaxillary. In: Dunn R, Dilley S, Brookes J, et al, editors. The emergency medicine manual. 4th ed. Adelaide: Venom Publishing, 2006: 267.

(Received 8 Aug 2009, accepted 26 Oct 2009) 